\title{
The effect of shock loading on the performance of a thermophilic anaerobic contact reactor at constant organic loading rate
}

\author{
Elif Senturk" ${ }^{*}$, Mahir Ince ${ }^{2}$ and Guleda Onkal Engin ${ }^{2}$
}

\begin{abstract}
The influences of organic loading disturbances on the process performance of a thermophilic anaerobic contact reactor treating potato-processing wastewater were investigated. For this purpose, while the reactor was operated at steady state conditions with organic loading rate of $5.5 \mathrm{~kg} \mathrm{COD} / \mathrm{m}^{3}$. day, an instant acetate concentration increase $(1 \mathrm{~g} / \mathrm{L})$ was introduced to the reactor. During the shock loading test of acetate, it was observed that the overall process performance was adversely affected by all the shock loading, however, the system reached steady state conditions less than 24 hours of operation indicating that thermophilic anaerobic contact reactor is resistant to shock loading and be capable of returning its normal conditions within a short time period.
\end{abstract}

Keywords: Thermophilic, Anaerobic contact reactor, Shock loading, Recovery, Stability

\section{Introduction}

The wastewater from potato processing industry can be considered as a complex wastewater because of rather high concentrations of suspended solids, high content of insoluble COD fraction and significant quantities of potential foaming substances, such as proteins and fats $[1,2]$. Therefore these wastewaters could only be discharged into municipal sewer system or receiving media after the reduction of the pollutants to acceptable levels. These wastewaters are usually treated with various combinations of aerobic and anaerobic biological processes due to high concentrations of readily biodegradable compounds [1,3-6].

It is known that both the substrate retention time and the degree of contact between influent substrate and living microorganism population affect the performance of anaerobic reactors [6]. Both of these parameters are a function of the mixing conditions ensured in the reactor. Mixing provides a suitable medium for the microorganisms to remain in suspension, as well as, for the biogas produced to leave the system [7]. Additionally, mixing ensures heat transfer, and a homogeneous substrate

\footnotetext{
*Correspondence: e.senturk@gyte.edu.tr

'Department of Environmental Engineering, Gebze Institute of Technology, Kocaeli, Turkey

Full list of author information is available at the end of the article
}

distribution by preventing stratification and formation of surface crust [8].

Hydraulic retention time (HRT) is another important design parameter for digesters. For a given volume of wastewater, a shorter HRT is an indication of a smaller digester and, therefore, a more cost-effective solution. In order to reduce HRT, temperature or solid retention time (SRT) increase were applied previously [9]. Highrate processes come forward to overcome this drawback of anaerobic treatment $[10,11]$.

The anaerobic contact reactor, a typical example of high-rate anaerobic processes, can be classified as the counterpart of the aerobic activated sludge process. Both reactors are characterised with a constant, mechanical mixing of substrate with recycled biomass. Anaerobic contact reactors have been used extensively in the food processing industry to treat typical high strength effluents with relatively high suspended solids $[6,12]$. These reactors can be operated under different temperature ranges. Temperature can affect biochemical reactions in a number of ways, i.e. reaction rates increase with increasing temperature by the Arrhenius equation [6]. Increased reaction rates would reduce retention times and therefore capital and operational costs would decrease. Moreover, increased organic solids destruction would decrease the waste sludge while yielding more biogas $[6,13]$. 
The aim of this study is therefore to examine the effect of high acetate concentration on the performance and stability of the thermophilic anaerobic contact reactor (TACR). For this purpose, the most important operational parameters such as $\mathrm{pH}$, alkalinity, total volatile acid concentration and biogas composition were monitored.

\section{Materials and methods}

\section{Wastewater source and characterisation}

The wastewater, used in this study, was obtained from a potato-processing factory. The wastewater was taken from the pipeline just after peeling and cutting processes were carried out. The characteristics of the wastewater can be found in Table 1 . The COD/N/P ratio of the wastewater used was found to be $275 / 10 / 1$.

\section{Thermophilic anaerobic contact reactor configuration and operation conditions}

The thermophilic anaerobic contact reactor (TACR) used in this study can be seen in Figure 1. The contact reactor and all the other components of the system were made of stainless steel. The contact reactor was constructed as a completely closed jacketed vessel, so that it was leak-proof and resistant to pressures up to 2 bars. The piping was installed using teflon and stainless steel pipes that are resistant to pressure and acidic/basic conditions. The control volume of the contact reactor was 33 L. Working with such a reactor would allow possible scaling up from laboratory scale to full scale easily. The feed tank was mixed continuously at a rate of $80 \mathrm{rpm}$ to avoid precipitation of the particulate matter (starch). Anaerobic granular sludge taken from an anaerobic digester of a sewage treatment plant in a potatoprocessing factory was used as inoculum. In order to keep the reactor at thermophilic conditions, i.e. $55 \pm 2{ }^{\circ} \mathrm{C}$, a $10 \mathrm{~L}$ heater tank was attached to the system. For this purpose, three PT100 temperature sensors were used. The $\mathrm{pH}$ of the system was monitored and controlled continuously with a $\mathrm{pH}$ probe and the $\mathrm{pH}$ value was adjusted by $\mathrm{NaOH}$ when necessary. The water used in

Table 1 The characteristics of the wastewater used (after peeling and cutting processes)

\begin{tabular}{lll}
\hline Parameter & Unit & Average \\
\hline $\mathrm{TCOD}$ & $\mathrm{g} / \mathrm{L}$ & 5.50 \\
$\mathrm{BOD}_{5}$ & $\mathrm{~g} / \mathrm{L}$ & 4.50 \\
Alkalinity & $\mathrm{g} \mathrm{CaCO} / \mathrm{L}$ & 2.25 \\
$\mathrm{pH}$ & - & 7.50 \\
Total Kjeldahl nitrogen & $\mathrm{g} / \mathrm{L}$ & 0.23 \\
Sulphate & $\mathrm{g} / \mathrm{L}$ & 0.45 \\
Total solids & $\mathrm{g} / \mathrm{L}$ & 4.90 \\
Total volatile solid matter & $\mathrm{g} / \mathrm{L}$ & 4.45 \\
\hline
\end{tabular}

gas washing was acidified to $\mathrm{pH} 3$ by the addition of $\mathrm{HCl}$ and $\mathrm{NaCl}$ in order to prevent biogas dissolution. In order to prevent microorganism loss, a heat-insulated precipitation tank was also attached to the system. For the overall control of the system, a programmable logic controller (PLC/Siemens S7 300) was used, and data acquisition and visualization was carried out using WinCC SCADA (Siemens).

In order to study the effects of different operational parameters, the TACR was continuously operated for over a year (Şentürk et al., 2010), before the organic shock loading study was carried out. In order to examine the effect of high acetate concentration on the performance and stability of the TACR, acetate concentration in the reactor was increased to $1 \mathrm{~g} / \mathrm{L}$ instantly, when the reactor was operated at organic loading rate of $5.5 \mathrm{~kg}$ $\mathrm{COD} / \mathrm{m}^{3}$. day $(\mathrm{HRT}=1$ day). During the feeding of shock acetate loading to the system, no other changes were made in the raw wastewater characteristics or flow rate. The response of the anaerobic culture in the reactor to this high acetate concentration was then observed at constant organic loading rate.

\section{Analytical methods}

All the chemicals used were of analytical reagent grade and water used during the experiments was laboratory distilled water. The analytical methods, which were used in order to monitor the performance of the system, were performed using the methods given in the Standard Methods [14]. The COD and $\mathrm{BOD}_{5}$ analyses were carried out according to the STM $5220 \mathrm{C}$ and STM $5210 \mathrm{~B}$ methods, respectively [14]. The TKN analyses were performed using the STM 4500-Norg B Macro-Kjeldahl [14]. The sulphate analyses were carried out using the STM 4500-SO $\mathrm{SO}_{4}^{2-}$ method [14]. The alkalinity and total volatile fatty acid concentrations were determined according to STM 2320 B and STM 5560 C methods, respectively [14]. Acetic acid concentrations were conducted by a Gas Chromatography (Agilent) equipped with FID detector and a Zebran ZB-Wax capillary column, $30 \mathrm{~m} \times$ $250 \mu \mathrm{m} \times 0,50 \mu \mathrm{m}$. Helium was used as the carrier gas. The oven temperature was initially set at $100^{\circ} \mathrm{C}$ for $1 \mathrm{~min}$ increasing $20^{\circ} \mathrm{C} / \mathrm{min}$ to $120^{\circ} \mathrm{C}$ and then increasing $6.13^{\circ} \mathrm{C} /$ min to $205^{\circ} \mathrm{C}$. The total duration was 15.87 minutes. The detector temperature was $240^{\circ} \mathrm{C}$. The samples taken from the reactor were centrifuged for 15 minutes at $10000 \mathrm{rpm}$ at room temperature and the supernatant of the sample was analysed accordingly. Additionally, the total solid matter and total volatile solid matter concentrations were also determined (STM 2540 B and STM 2540 C methods) [14].

The biogas produced was measured cumulatively using a gas-meter (Ritter) and the components $\left(\mathrm{CH}_{4}, \mathrm{CO}_{2}\right.$, $\mathrm{H}_{2}$ ) were analysed by a Gas Chromatography (Agilent) 


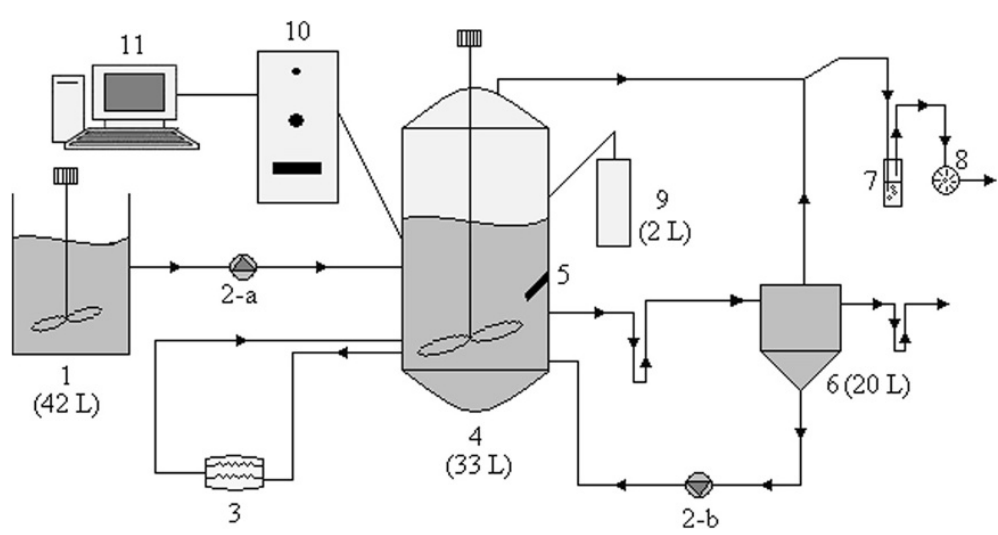

Figure 1 The schematic view and the flow chart of the TACR used in this study; 1) Feed tank, 2- Peristaltic Pump, 3) Heater, 4) Thermophilic Anaerobic Contact Reactor - TACR, 5) pH-meter, 6) Separation Tank, 7) Gas washing, 8) Gas-meter, 9) NaOH tank, 10) PLC Panel, 11) Computer.

using HP Plot Q + Molecular Sieve column, $60 \mathrm{~m} \times$ $530 \mu \mathrm{m} \times 400 \mu \mathrm{m}$. Argon was used as the carrier gas with a gas flow of $4 \mathrm{~mL} / \mathrm{min}$. The oven temperature was initially set at $50^{\circ} \mathrm{C}$ for $5 \mathrm{~min}$ increasing $5^{\circ} \mathrm{C} / \mathrm{min}$ to $80^{\circ} \mathrm{C}$ and kept at $80^{\circ} \mathrm{C}$ for 3 minutes, then increasing $10^{\circ} \mathrm{C} /$ min to $100^{\circ} \mathrm{C}$. The total duration was 16 minutes. The temperature of TCD (Thermal Conductivity Detector) was $200^{\circ} \mathrm{C}$.

\section{Results and discussions}

This study investigated the adverse effects of high acetate loading on a high-rate anaerobic contact reactor operated under thermophilic conditions. The organic shock loading was introduced to the system by dramatic increase of acetate concentration. It should be noted that before the organic shock loading study, the reactor was continuously run under steady-state conditions for over a year. The findings are discussed in the following sections.

\section{$\mathrm{pH}$ and alkalinity}

During the operation of a digester, $\mathrm{pH}$ is one of the most important factors and it is well known that anaerobic microbial activity is the highest in the $\mathrm{pH}$ range of $6.8-$ 8.5 [15-17]. Additionally, the alkalinity of the anaerobic reactor should be maintained as close to the operating range as possible and there might be a need for addition of alkaline solutions in order to adjust $\mathrm{pH}$ especially during the acetogenesis phase. The $\mathrm{pH}$ fluctuations can affect both the bacterial growth and their activity in organic matter degradation adversely [18]. Therefore, to keep pH in a specified region is of importance.

The system's response to acetate loading was monitored from the point of $\mathrm{pH}$ variations. As can be seen from Figure 2, the $\mathrm{pH}$ fluctuation after the addition of high concentration acetate was not significant due to buffering capability of wastewater used. The decrease in $\mathrm{pH}$ in the initial period after the shock loading can be associated to an increase in free hydrogen and acetate concentration in the reactor which is a result of the imbalance between fermentation bacteria and methanogens [19-21]. After the first 5 hours, the $\mathrm{pH}$ of the system began to increase to reach its steady-state values. 14 hours after instant high concentration acetate addition, the fluctuation in $\mathrm{pH}$ ceased and the system reached steady state conditions. Less extensive oscillations were observed in the $\mathrm{pH}$ values, due to the settlement tank used in the system. Throughout the study, alkalinity fluctuations rarely encountered, indicating buffering capability of the system. During the study, the VFA/Alkalinity ratio $(0,10-0,30)$ was almost always below the limit value of 0,33 [22].

\section{Volatile fatty acids}

In this study, another important parameter which needs to be observed was VFA. The total VFA and effluent acetic acid concentration change with time is given in Figure 3. As can be seen from Figure 3, the high values of both total VFA and acetic acid concentrations began

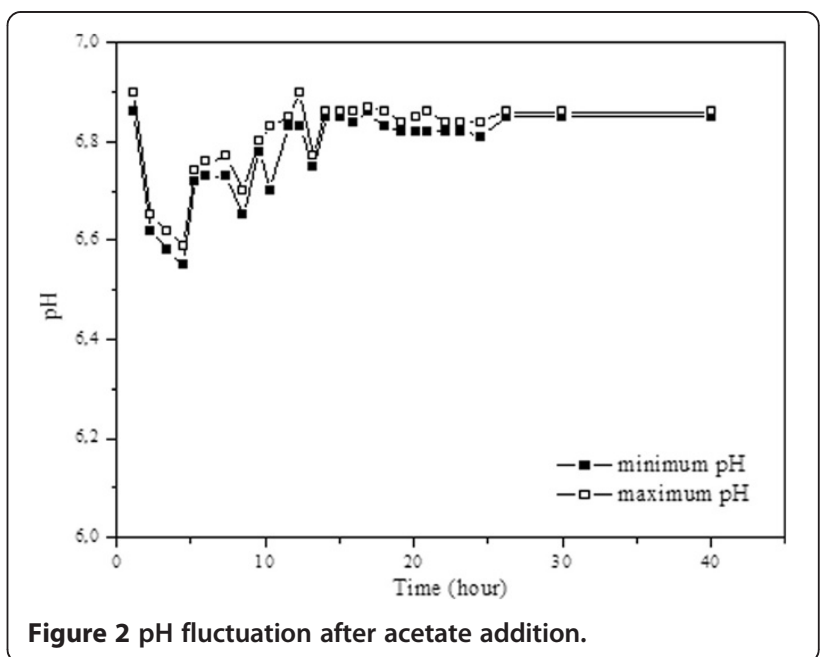




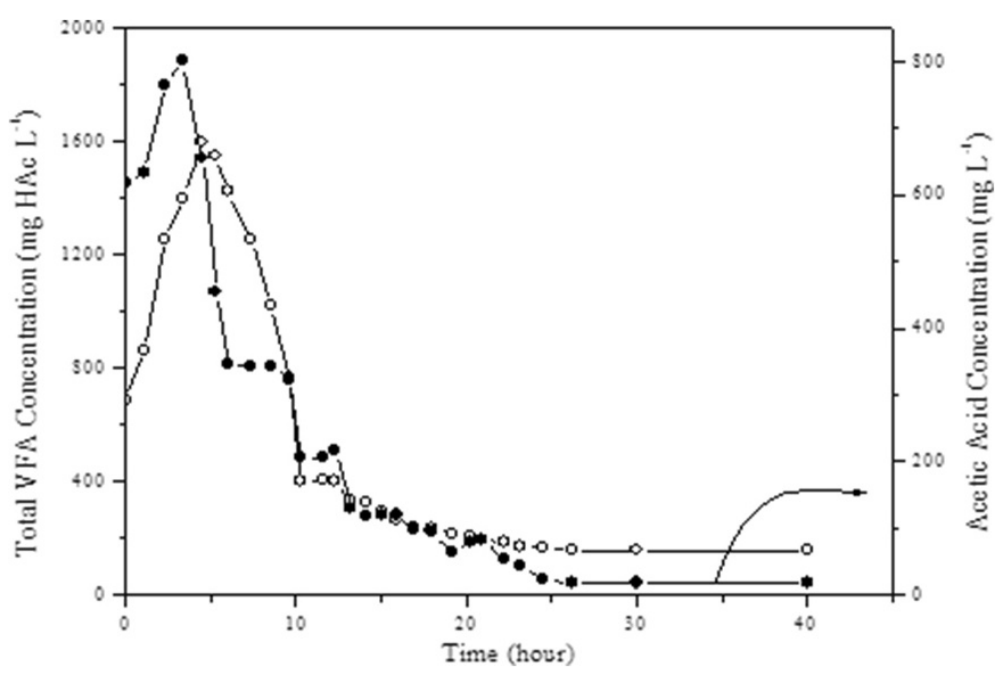

Figure 3 Effluent total VFA and acetic acid concentration.

to decrease after 5 hours of operation due to rapid conversion of acetate into methane by methanogens. The shock loading effect was tolerated due the use of contact reactor with a settlement tank. Another important result of this study was that the increase in acetate concentration and the total VFA concentration at the initial hours had quite similar trends indicating other VFA components in the system was insignificant. The GC analyses of volatile fatty acids confirmed this, as well. The total VFA concentration reached the steady state conditions within 24 hours.

\section{Biogas}

Biogas composition varies depending on feedstock, digester type and chemical addition [23]. Additionally, the amount of biogas produced during anaerobic digestion depends on the feed organic matter content, the total volatile solid matter and the $\mathrm{C} / \mathrm{N}$ ratio. The most known composition of biogas has about 60\% methane, 35\% carbon dioxide and about $5 \%$ the other gases [24,25].

The cumulative biogas amount generated in the reactor and major constituents of biogas composition are given in Figure 4. Because HRT was low (0,96 day), fermentative hydrogen producing bacteria might have washed out from the reactor [26]. However, it was reported that hydrogen gas is produced via oxidation during the conversion of long-chain fatty acids [12]. In the case of our study, it was thought that hydrogen-consuming microorganisms, such as methanogens reduce the hydrogen gas produced during this conversion. The deterioration of hydrogen

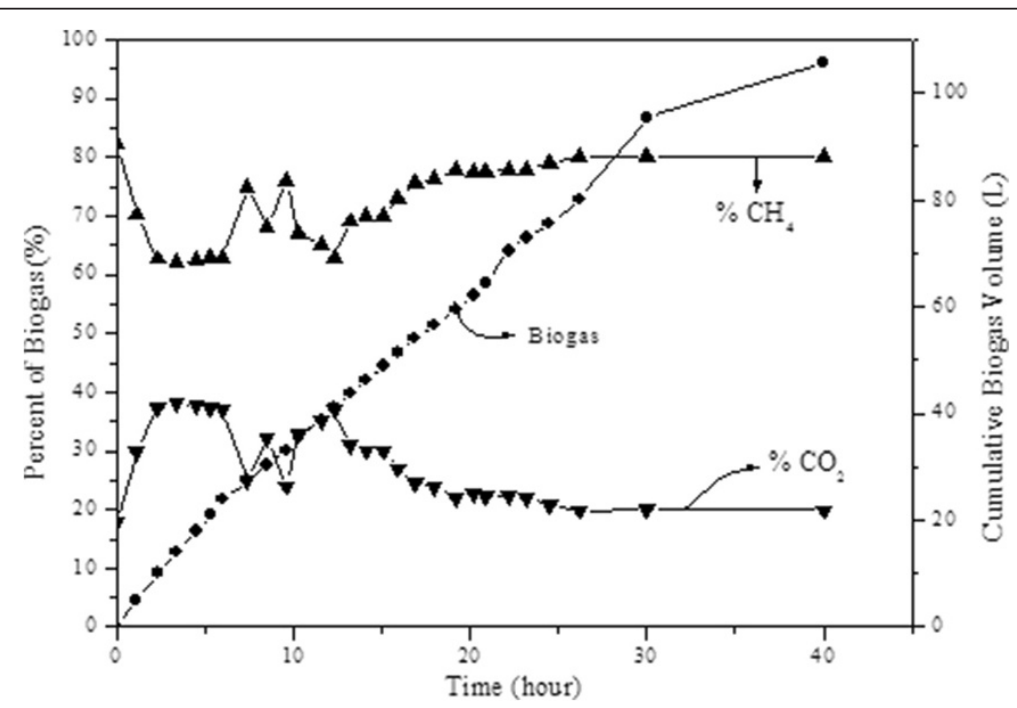

Figure 4 Cumulative biogas and percent of composition of biogas. 
gas production with increasing substrate concentration was well in accordance with other studies [27-29]. As can be seen from Figure 4, after loading, biogas generation increased. Increase in cumulative biogas amount was the highest within the first few hours after acetate loading, indicating that methanogens were able to use acetate rapidly. It was observed that biogas generation decreased in parallel to acetate usage. After 20 hours of operation, the steady state conditions were reached. With regard to the composition of produced biogas, it was significant that, within the first two hours, although methane percentage in biogas decreased, carbon dioxide percentage increased due to generation of carbon dioxide as a result of used alkalinity by volatile fatty acids. After the first 2 hours, gas composition was observed to reach stable values and no change in gas composition was observed for about 5 hours.

However, fluctuations in biogas composition started again after 7 hours of operation and these fluctuations continued for about 20 hours. Only after 14 hours, methane percentage in biogas started to increase. However, the negative impact of high acetate concentration on methane bacteria did not last long and steady state conditions were reached after the first 20 hours of operation following shock loading.

\section{Conclusions}

One of the most important features of the anaerobic contact reactors is that they are completely mixed reactors having a settlement tank. Anaerobic reactors, with continuous mixing facilities, are considered to be high-rate reactors from the point of mass transfer between substrate and microorganisms. Owing to this characteristic, the anaerobic contact reactor used in this study was found to be less affected by organic shock loading. When overall data were evaluated, thermophilic anaerobic contact reactor was found to be resistant to shock loading and can become stable only about in 20 hours.

\section{Competing interests}

The authors declare that they have no competing interests.

\section{Authors' contributions}

ES and $\mathrm{Ml}$ carried out all experimental design, experimental work, data analysis and data interpretation. GOE extended help in data interpretation and supervised the study. All authors have read and approved the final manuscript.

\section{Acknowledgment}

This study was supported by the Gebze Institute of Technology Research Fund (Grant No. 2008-A-21).

\section{Author details}

'Department of Environmental Engineering, Gebze Institute of Technology, Kocaeli, Turkey. ${ }^{2}$ Department of Environmental Engineering, Yildiz Technical University, Davutpasa Campus, Istanbul, Turkey.

Received: 18 March 2013 Accepted: 5 May 2014

Published: 12 May 2014

\section{References}

1. Kalyuzhnyi S, Estrada De Los Santos L, Rodríguez-Martínez J: Anaerobic treatment of raw and preclarified potato-maize wastewaters in a UASB reactor. Bioresour Technol 1998, 66:195-199.

2. Barampouti EMP, Mai ST, Vlyssides AG: Dynamic modeling of biogas production in an UASB reactor for potato processing wastewater treatment. Chemosphere 2005, 58:439-447.

3. Austermann-Haun U, Seyfried CF: Anaerobic aerobic wastewater treatment plant of a potato chips factory. Water Sci Technol 1992, 26:2065-2068.

4. Banerjee A, Elefsiniotis P, Tuhtar D: The effect of addition of potatoprocessing wastewater on the acidogenesis of primary sludge under varied hydraulic retention time and temperature. J Biotechnol 1999, 72:203-212.

5. Kryvoruchko V, Machmüller A, Bodiroza V, Amon B, Amon T: Anaerobic digestion of by-products of sugar beet and starch potato processing. Biomass Bioenergy 2009, 33:620-627.

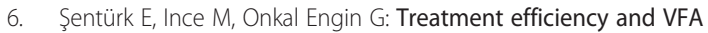
composition of a thermophilic anaerobic contact reactor treating food industry wastewater. J Hazard Mater 2010, 176:843-848.

7. Karim K, Hoffmann R, Thomas K, Al-Dahhan MH: Anaerobic digestion of animal waste: waste strength versus impact of mixing. Bioresour Technol 2005, 96:1771-1781.

8. Kaparaju P, Buendia I, Lars El, Angelidakia I: Effects of mixing on methane production during thermophilic anaerobic digestion of manure: lab-scale and pilot-scale studies. Bioresour Technol 2008, 99:4919-4928.

9. Dugba PN, Zhang R: Treatment of dairy wastewater with two-stage anaerobic sequencing batch reactor systems-thermophilic versus mesophilic operations. Biorcsource Technol 1999, 68:225-233.

10. Nachaiyasit S, Stuckey DC: Effect of low temperature on the performance of an anaerobic baffled reactor (ABR). J Chem Technol Biotechnol 1997, 69:276-284.

11. Krishna GVTG, Kumar P, Kumar P: Treatment of low strength complex wastewater using an anaerobic baffled reactor (ABR). Bioresour Technol 2008, 99:8193-8200.

12. Abdel-Halim WS: Anaerobic Municipal Wastewater Treatment. Hannover: Universität Hannover Inst. f. Siedlungswasserwirtsch; 2005.

13. Buhr HO, Adrews JF: The thermophilic anaerobic digestion process: review paper. Water Res 1977, 11:129-143.

14. APHA: Standard Methods for the Examination of Water and Wastewater. 21st edition. Washington, DC: American Public Health Association; 2005.

15. Lastella G, Testa C, Cornacchia G, Notornicola M, Voltasio F, Sharma VK Anaerobic digestion of semi-solid organic waste: biogas production and its purification. Energy Convers Manag 2002, 43:63-75.

16. Zhao Q-B, $\mathrm{Yu} \mathrm{H}-\mathrm{Q}$ : Fermentative $\mathrm{H}_{2}$ production in an upflow anaerobic sludge blanket reactor at various $\mathrm{pH}$ values. Bioresour Technol 2008, 99:1353-1358.

17. Rongrong L, Xujie L, Qing T, Bo Y, Jihua C: The performance evaluation of hybrid anaerobic baffled reactor for treatment of PVA-containing desizing wastewater. Desalination 2011, 271:287-294.

18. Wu X, Yao W, Zhu J: Effect of pH on continuous biohydrogen production from liquid swine manure with glucose supplement using an anaerobic sequencing batch reactor. Int J Hydrog Energy 2010, 35:6592-6599.

19. Denac M, Miguel A, Dunn IJ: Modeling dynamic experiments on the anaerobic degradation of molasses wastewater. Biotechnol Bioeng 1988, 31:1-10.

20. Hickey RF, Switzenbaum MS: The response and utility of hydrogen and carbon monoxide as process indicators of anaerobic digesters subject to organic and hydraulic overloads. Res J Water Pollut Contr Fed 1991, 63:129-140.

21. Strong GE, Cord-Ruwisch R: An in situ dissolved-hydrogen probe for monitoring anaerobic digesters under overload conditions. Biotechnol Bioeng 1995, 45:63-68.

22. Busu Z, Sulaiman A, Hassan MA, Shirai Y, Abd-Aziz S, Yacob S, Wakisaka M: Improved anaerobic treatment of palm oil mill effluent in a semi-commercial closed digester tank with sludge recycling and appropriate feeding strategy. Pertanika J Trop Agr Sci 2010, 33:27-37.

23. Mata-Alvarez J, Macé S, Llabrés P: Anaerobic digestion of organic solid wastes. An overview of research achievements and perspectives. Bioresour Technol 2000, 74:3-16.

24. Igoni AH, Ayotamuno MJ, Eze CL, Ogaji SOT, Robert SD: Designs of anaerobic digesters for producing biogas from municipal solid-waste. Appl Energy 2008, 85:430-438. 
25. Osorio F, Torres JC: Biogas purification from anaerobic digestion in a wastewater treatment plant for biofuel production. Renew Energy 2009, 34:2164-2171.

26. Guo WQ, Ren NQ, Chen ZB, Liu BF, Wang XJ, Xiang WS, Ding J:

Simultaneous biohydrogen production and starch wastewater treatment in an acidogenic expanded granular sludge bed reactor by mixed culture for long-term operation. Int J Hydrogen Energ 2008, 33:7397-7404.

27. Oh YK, Kim SH, Kim MS, Park S: Thermophilic biohydrogen production from glucose with trickling biofilter. Biotechnol Bioeng 2004, 88:690-698.

28. Van Ginkel SW, Logan B: Increased biological hydrogen production with reduced organic loading. Water Res 2005, 39:2819-2826.

29. Zhang ZP, Tay JH, Show KY, Yan R, Liang DT, Lee DJ: Biohydrogen production in a granular activated carbon anaerobic fluidized bed reactor. Int J Hydrogen Energ 2007, 32:185-191.

doi:10.1186/2052-336X-12-84

Cite this article as: Senturk et al:: The effect of shock loading on the performance of a thermophilic anaerobic contact reactor at constant organic loading rate. Journal of Environmental Health Science \& Engineering 2014 12:84

\section{Submit your next manuscript to BioMed Central and take full advantage of:}

- Convenient online submission

- Thorough peer review

- No space constraints or color figure charges

- Immediate publication on acceptance

- Inclusion in PubMed, CAS, Scopus and Google Scholar

- Research which is freely available for redistribution 